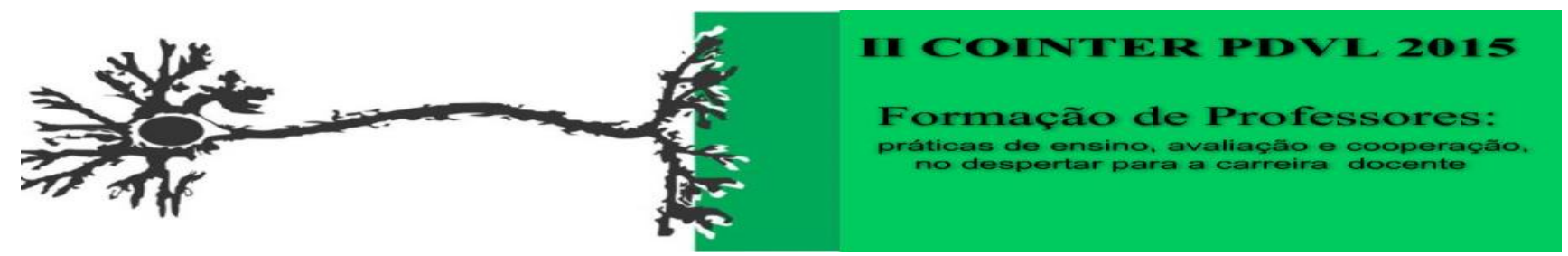

\title{
PROJETO: DESPERTANDO VOCAÇÕES PARA A LICENCIATURA EM GEOGRAFIA: Desafios e possibilidades de ser professor.
}

\author{
Apresentação: Pôster
}

Raphael Fontoura da Silva ${ }^{1}$; Dilton Arlindo dos Santos Junior ${ }^{2}$; Jose Henrique Duarte Neto ${ }^{3}$

\section{Introdução}

Este projeto articula-se ao Programa Desenvolvendo Vocações para as Licenciaturas PDVL. A natureza deste projeto sugere a articulação entre ensino pesquisa e extensão. Foi elaborado, a partir da formulação de uma questão: quais as causas que contribuem para a baixa procura, por parte dos estudantes aspirantes ao ensino superior, pelos cursos de licenciatura? Dados de pesquisa a respeito da profissão docente tem demonstrado que a cada ano diminui, de forma significativa, a busca por cursar as licenciaturas, ocasionando uma crise na profissão, em decorrência da falta de professores, devidamente habilitados para o exercício do magistério. Os esforços no sentido de buscar alternativas e soluções para o problema tem surgido. A experiência empírica e a produção de estudos e pesquisas a respeito da carreira docente, têm demonstrado que ao longo dos anos não tem sido do interesse dos jovens a escolha da profissão de professor.

A importância deste projeto, reside também na capacidade da crítica, que a prática extensionista pode suscitar no sujeito envolvido nesse processo e a possibilidade de comprometimento, com a construção de uma educação de qualidade, em todos os níveis. O propósito está, também, na tentativa de tributar na construção de uma educação, cujas práticas educativas, estejam assentadas em outras bases sociais. Consideramos como eixos importantes e articuladores da formação do educador a compreensão do fenômeno educativo, do papel da escola, seus determinantes sociais e condicionamentos históricos. Nesta perspectiva as atividades de extensão contribuem, de forma significativa, parra no contato com o mundo da profissão, em nosso caso a docência, na independência intelectual do estudante, bem como na formação de valores, como a disciplina acadêmica e o comprometimento com as tarefas de construção assumidas, por ocasião do processo extensionista desenvolvido.

\footnotetext{
${ }^{1}$ Licenciatura em Geografia, IFPE (campus Recife), raphael.fontoura@hotmail.com

${ }^{2}$ Licenciatura em Geografia, IFPE (campus Recife), santos.junior160@gmail.com

${ }^{3}$ Prof. Dr. José Henrique Duarte Neto, IFPE (campus Vitória de Santo Antão), jose.neto@reitoria.ifpe.edu.br
} 


\section{Fundamentação Teórica}

O nosso referencial teórico requer uma atividade extensionista para além de algo essencialmente prático. Tratamos de desenvolver as nossas ações de modo que priorizasse a relação entre teoria e prática. Assim, desenvolvemos uma metodologia de trabalho que pode, ao abordar o campo de extensão, considerá-lo a partir das relações sócias históricas, que favorecem os processos de produção e reprodução da existência do ser social. Desse modo, é importante um referencial teórico-metodológico que perceba o processo de extensão como totalidade, que requeira tomar os seus diversos aspectos em estreita relação de dependência e de determinações recíprocas. Optamos por uma abordagem dialética, de compreensão e a apropriação do movimento da realidade, por compreender que para dar conta da complexidade do mundo com suas múltiplas dimensões, precisamos utilizar um método que tenha as suas categorias de análises extraídas da própria realidade, apreendendo e interpretando as suas relações, o seu movimento e as mudanças inerentes à sua natureza (LEFEBVRE, 1979) para que a ela retorne, em um processo de construção e reconstrução do objeto de intervenção, do extensionista. Uma metodologia que permita ordenar, disciplinar e sistematizar o processo de trabalho, sendo capaz de conceber esta realidade em sua totalidade, mas que também não ignore, por outro lado, aspectos que lhes são singulares, particulares e que favoreça relações entre aspectos de natureza específica e geral, entre objetividade e subjetividade (FRIGOTO, 2000).

\section{Metodologia}

As atividades foram desenvolvidas, pelos extensionistas que estabeleceram contato com uma escola secundária da rede estadual de Pernambuco, no município do Recife. Visando desenvolver o projeto de pesquisa e extensão. Ao mesmo tempo os estudantes extensionista, com a ajuda do professor/orientador, de modo a apresentar o programa e sensibilizar a comunidade para atuar na atividade do trabalho. Para fins de diagnóstico, deve-se aplicar um instrumento de coleta de informações (questionário) com vistas à identificar o interesse dos estudantes do ensino médio pela carreira do magistério em geral, e da licenciatura em geografia em particular. O questionário foi elaborado com o intuito de auto-resposta, com perguntas que visavam o interesse dos alunos em seguir a carreira docente. Os dados foram analisados para gerar gráficos que subsidiasse as futuras intervenções nas escolas visando levar em consideração o interesse dos alunos pelas licenciaturas e 
em particular, pela licenciatura em geografia.

\section{Resultados e Discussões}

O projeto obteve aceitação por parte dos estudantes, o que facilitou a execução do trabalho. A partir das atividades e questionários aplicados organizamos um banco de dados inicial que nos dará suporte para continuar a desenvolver métodos de intervenção que contribuam para despertar o interesse dos estudantes do ensino médio pela licenciatura em geografia. Contudo identificamos o reconhecimento dos alunos a respeito da carreira docente. Porém, muitos não desejam seguir a carreira por não se sentir atraído ou estimulado, principalmente no que diz respeito a parte da remuneração e condições de trabalho oferecido pelas escolas.

\section{Conclusões.}

$\mathrm{O}$ nosso projeto ao definir as atividades extensionista articula-as à pesquisa, e assim contempla a coleta de informações com base na aplicação de um questionário nas escolas de ensino médio, com os alunos concluintes ou pré-concluintes do ensino médio, com a finalidade de identificar os seus interesses, em cursar uma licenciatura em nível superior, particularmente em geografia. Os resultados coletados indicaram e reafirmaram o pouco interesse dos estudantes que participaram da pesquisa, na escola estadual Olinto Victor, que fica situada no bairro da Várzea no município do Recife.

\section{Referências}

FRIGOTO, Gaudêncio. O enfoque da dialética materialista histórica na pesquisa educacional. Metodologia da Pesquisa Educacional. 6. ed. São Paulo: Cortez, 2000.

LEFEBVRE, Henri. O Marxismo. 5. ed. São Paulo: Difel, 1979. 